bears more resemblance to acute general eczema than any other known disease; but it differs considerably from this disease in the extent and severity of the dermal inflammation and thickening, in the profuseness of the exfoliation, and in the definiteness of its course.

The only treatment which availed was the external application of germicides, and the administration of stimulants.

The author then proceeded to consider the question of etioligy. Age was certainly a very important predisposing condition, for although the infirmary contained a relatively large number of aged persons, still it was shown that if the inmates were classed according to age into decades, the percentage of those attacked in the earlier decades was considerably smaller than the percentage in the later decades. Thus, of those between ten and 20,6 per cent.; between 20 and 30,7 per cent. ; between 30 and 40,6 per cent. ; between 40 and 50,17 per cent. ; between 50 and 60,24 per cent.; between 60 and $70,3^{8}$ yer cent. ; between 70 and 80,35 per cent.; and between 80 and 90,24 per cent. Males seemed more prone to take the disease than females, in the proportion of $2+$ to 16 per cent. After discussing and excluding food, soap, scabies, and water as possible exciting causes, the question of epidemic influences, such as climate and season, and contagion, were referred to.

The clinical phenomena of the disease are alone almost sufficient to stamp it as contagious; its more or less definite course, the constitutional disturbance, the marked effect of germicides, the wave-like manner in which the outbreak had come and gone, and the fact that six out of the eleven, who were the only ones out of 202 healthy persons to contract the disease, were "helpers" tending on sufferers from the disease. Nevertheless, the contagion is evidently of a feeble order, and seems to require several important predisposing conditions, especially including old age and sickness, or "hos" pitalism" for its development. The bacteriology and several other points connected with this strange outbreak required careful investigation, and would form the basis of a future communication.

Gelatin as a Re-agent for the PURfose of Discovering Tryptic Enzymes. By Dr. Claudio Fermi. Archiv. $f$. Hygiene. Bd. xii, Hefl, 3.-The author boils 5 to ro grains of pure gelatin with $93 \mathrm{cc}$. of an aqueous solution of Thymol until the gelatin is dissolved. The solution is kept in test tubes. A few cc's, of the fluid to be tested is poured upon the cold solidified gelatin; if an enzyme is present a greater or less amount of solution occurs; on the other hand, if an enzyme is absent, no solution in even five or six days takes place. Of course, the experiment must be made at temperatures below the melting point of the gelatin, and it is not applicable to liquids which act chemically upon gelatin.

\section{RESULTS OF SANITARY WORK IN DUBLIN.}

By Sir C. A. Cameron, M.D., D.P.H.Camb."

DUbLIN is situated on both sides of the river Liffey, and its suburbs spread round the Bay of Dublin. It is well supplied with main sewers, the contents of which are discharged into the river. A large portion of the city lies so low that the floors of basement stories are below high-water level, consequently, the sewers cannot continuously discharge their contents into the river. The mouths of the sewers are provided with valves which open outwards, and which are closed when the water in the river rises to the level of the sewer mouth. The sewers situated near the mouth of the river are often sealed during the greater part of the twenty. four hours. In order to prevent their contents from becoming impounded to such an extent as to prevent the drainage from the houses entering the sewers, powerful steam pumps are employed to lift the surplus sewage to a level above high-water. It will therefore be seen that Dublin is unfavourably placed with respect to its sewage, which is retained for a long time in the sewers, and which, when discharged into the river, constitutes a nuisance therein, which, especially in warm weather, is greatly complained of. At the present time the Municipal Council is seriously considering the question of main drainage. At no distant date we may expect to see the Dublin sewage either conveyed to a distant point and discharged into the open sea, or subjected to some precipitation process; on economic and other grounds, I prefer the latter method.

Another disadvantage under which Dublin suffers is the decayed condition of a large proportion of the tenement houses. There are about 54,000 families in Dublin, inhabiting about 24,000 houses; 32,000 families occupy 8,000 houses, and 22,000 the remaining houses. The 32,000 families have I $\frac{1}{2}$ rooms on the average per family. The tenement houses were for the most part originally built each for a single family, and many of them now accommodate from 4 to 10 families. These houses, it need hardly be said, are ill-adapted for the accommodation of several families, and many of them are so old that it is almost impossible to keep them in proper repair.

Late in 1879 I became the chief medical officer of health for Dublin, and soon after the whole sanitary department of the municipality was placed in my charge ; I was appointed the "Executive" as well as the "Medical" Officer of Health, and the power of appointing and dismissing the sanitary officers was given to me.

In 1879 the death-rate in the Dublin Metropolitan area (city and suburbs), was $35^{\circ} 7$ per 1,000 persons living; and in 1880 it was $35^{\circ} 9$ per $x, 000$.

* Sir C. A. Cameron's 29th Annual Report on the IIealth of Dublin, 1890. 
In 1879 the death-rate in the City of Dublin was 37.5 , and in 1880 it was 37.8 per 5,000 .

In 1879 the death rate caused by the principal zymotic diseases was 5.6 per $x, 000$ persons living in the whole metropolitan area, and 6.2 in the city. In 1880 the rate was 7.2 in the whole area, and 7.9 in the city.

This was the territle state of things existing in Dublin when I became the chief health officer. The measures which I proposed should be taken to improve the sanitary state of Dublin were chiefly as follows :-

1. To provide better dwellings for the very poorest classes of the community.

2. To de-tenant and close the tenement houses which were most unfit for human habitation.

3. To compel the owners of tenement houses to keep them in tenantable order.

4. To cleanse daily, by the Corporation workmen, the yards of the tenement houses and their sanitary accommodation.

5. To abolish the privies and ashpits in connection with houses, tenement or private, and to substitute therefore water closets and portable ashbins.

I shall now briefly state how far my suggestions have been acted upon and the results.

I. The Corporation of Dublin, on consideration of my relort recommending the adoption of the provisions of the Labouring Classes Dwellings Acts, resolved in $188 \mathrm{I}$ to accede to my request. In I 888 two blocks of artizans' dwellings and a nightly lodging-house were erected by the Corporation on a portion of their own estate situated in Barrack Street; they comprise 144 separate dwellings and 100 beds for nightly lodgers. The dwellings are rented from 15 , $6 \mathrm{~d}$, to 5 s. per week. There are five shops which bring higher rents. This scheme cost $f_{27,500 ;}$ it has not been successful from a pecuniary point of view.

In 1890 , two-story houses were erected in Bowlane on the site owned by the Corporation; they comprise 86 self-contained dwellings.

Each house contains four distinct tenements : Two upon the ground floor and two upon the first floor.

The dwellings are built side by side in a continuous row, on each side of a new street, running north and soutb, thus giving the dwellings east and west aspects.

Each tenement consists of a living room $12^{\prime} 8^{\prime \prime} \times 12^{\prime} O^{\prime \prime}$; one bedroom, $10^{\prime} 6^{\prime \prime} \times 7^{\prime} 6^{\prime \prime}$; also a convenient sized scullery and a separate water closet, all $8^{\prime} 3^{/ /}$high. The weekly rent of this tenement on the upper floor is $2 \mathrm{~s}$. One of the two tenements on the upper floor contains a bed recess over the bottom flight of stairs, affording accommodation for two children or one adult, in addition to the bedroom accommodation. For this tenement 23. $6 \mathrm{~d}$. is charged.
On the ground floor the tenements are similar, but possess large gardens. The rent for the tene$m \in n t$ on the ground floor without the bed recess, but including garden (which is much appreciated), is 35., and for the tenement containing the bed recess under upper flight of stairs, 3 s. $6 \mathrm{~d}$.

It will be observed that the arrangement of the tenements is such that two tenements, possessing very ample accommodation and conveniences, with separate water closets, etc., for the sexes, can be obtained at the rent of $4 \mathrm{~s}$. $6 \mathrm{~d}$. for the two upper tenements; or that one ground floor tenement with garden, and one first floor tenement can be obtained for $5 \mathrm{~s}$.

A complete and perfect system of ventilation is provided by means of upcast and downcast flues to each room, the inlets and outlets of which are so placed as to prevent draughts, and a constant change of air is ensured, although the doors and windows may be closed.

The living room is provided with a cottage range and an enclosed cupboard, and the scullery has an earthenware sink supplied with cold water, also a coal-box adjoining the sink, and a meat-safe over the window, the latter being in three heights; the upper portion of the window and side panels of safe are filled in with perforated zinc.

The windows of the living rooms are $4^{\prime} \mathrm{o}^{\prime}$ wide, and extend up to the ceiling, thus causing the rooms to be both light and cheerful. The windows of bedrooms and scullery are also carried up to ceiling.

The buildings are all of concrete and fire-proof throughout, the upper floors being also constructed of concrete on iron joists. The roof is flat, similarly constructed, and covered with two thicknesses of ashphalte, and the whole area under the rooms on ground floor is covered with broken stones, concrete, and a layer of pitch and tar, $\frac{1}{2}$ thick, to ensure absolute dryness.

The landings and staircases are of concrete, covered with asphalte, and the floors of sculleries and water-closets are of concrete.

The whole scheme consists of 86 of these selfcontained dwellings, some of them with shops, and others with additional rooms, for which an increased rent is charged, according to accommodation. Applications largely in excess of the number of tenements to be let were received before the dwellings were completed. Every tenement is occupied, and no rent is in arrear, or has been lost since the dwellings were opened, and a large number of applicants are now on the books seeking vacancies as they occur.

The dwellings were erected for the accommodation of labourers; but widows and single women (seamstresses and others) are also received as tenants.

Mr. Dudgeon was the architect, and consulted with me as to details of the dwellings.

The Dublin Artisans' Dwellings Company have 
provided healthful dwellings for nearly ro,000 persons, and about $I, 000$ persons are provided for by the City and Suburban Workmen's Dwellings Company. Messrs. Guinness, Sons, and Co., brewers, bave provided dwellings for a large number of their workmen, and so have some other employers of labour. Altogether good dwellings have been lately erected capable of accommodating about 15,000 persons. It would, however, be desirable to provide improved dwellings for at least 50,000 persons.

2. From August 3 rst, 1879, up to December $31 \mathrm{st}, 1890,2,556$ insanitary houses have been detenanted and closed. More than one-half have been completely removed, and the others have been extensively repaired and rendered habitable. The houses that have been completely taken down have in a large number of cases not been replaced by new ones, as they were situated in close alleys and courts, or in other situations in which it was undesirable to build houses; $75^{8}$ cellar and kitchen dwellings have been closed since 1879 , as have also several hundred rooms in houses, portions of which were fit for occupation.

In one district-Wood Street, Arthurs' Lane, and Oliver's Alley-an area of more than one acre was cleared without any expense to the city, in the way of compensation to the owners of the houses. All the houses were detenanted under the provisions of the Public Health Acts (Ireland), 1874 and 1878 , and when they became ruinous they were pulled down. Clearances of a similar kind have been made in Bull Lane, Kennedy's and Ross Lanes, and in other localities.

In addition to the above-described clearances, two unhealthy sites were cleared under Cross's Act. They embraced an area of 7 acres, 3 roods, and 13 perches, upon which some of the most insanitary dwellings in Dublin were situated. The cost amounted to $£ 51,500$, or at the rate of $£ 5,97 \mathrm{I}$ per acre. The houses cleared away numbered 361 , and were inhabited by 2,603 persons.

The cleared sites were let by the Corporation to the Artisans' Dwellings Company, at a rent of $£ 390$ per annum, and they are now covered with artisans and labourers' dwellings.

Some very unhealthy dwellings were got rid of at my suggestion by making a new street (St. Augustine Street), at a cost of $£ 8,000$. Very bad dwellings were also got rid of within the last ten years by making two new streets (Lord Edward Street and Tara Street), but these improvements were not undertaken at my suggestion.

The money expended in clearing the Coombe and Plunkett Street areas and providing dwellings for the working classes amounted to $\mathscr{E 9 2}_{92}, 025$.

3. A vigorous inspection of tenement houses has been maintained since $x 879$, with the result that their condition has been materially-improved. In the inspectorial work, 23 officers are employed under my direction.
4. In Dublin, the ashpits and privies of private houses are cleansed by the Corporation. Finding that it was very difficult, and indeed impossible, to get the owners of the tenement houses to keep the yards, privies, and water-closets clean, I induced the Corporation to undertake this duty. It is now carried out at an annual cost of about $\sum_{3,000}$. This system has been, I believe, an important factor in improving the health of Dublin.

5. Before 1880 , water-closets were unknown in the tenement houses; some of them had no sanitary accommodation at all, whilst in many cases the privies were placed against the back walls of houses, and they communicated directly with the large and uncovered ashpits. The contents of the latter were, especially in wet weather, more or less liquid. The proximity of these ill-kept and rarely. cleansed privies and ashpits to the tenement houses produced, I am satisfied, great injury to health. I commenced at once an attack upon the privies, and in 1880,743 water-closets were substituted for them, nearly all in tenement houses. In $188 \mathrm{I}, * 603$ water-closets were substituted for privies.

In $1882 \mathrm{I}$ had a survey made, which showed that in all Dublin (City) there were $\mathrm{I}_{5}, 53 \mathrm{I}$ waterclosets and $\mathrm{II}, 269$ privies. About this time I reported strongly in favour of providing portable bins for the reception of house refuse, and since then every effort has been made to abolish the built ashpits and to substitute therefor the portable bins. At the close of 1890 there were $10,75^{2}$ Corporation dust-bins in use. Very few privies now remain, and in Dublin the water-carriage system of excreta bas nearly completely been established.

Amongst the sanitary measures taken for improving the health of Dublin, I may mention the thorough and gratuitous disinfection of infected dwellings, clothes and bedding. Infected beds are burned, and new ones given gratuitously in lieu of them. Disinfectants are given free to the working-classes. A laundry for infected linen has been established; public baths and wash houses have been provided in Tara Street; a public abattoir has been established, which, however, has not as yet been largely used; the inspection of dairies and cow-sheds is carried out by four inspectors; the Act for the compulsory notification of infective diseases has been adopted. Within the last ten years $£ 54,000$ has been expended in providing new sewers and machinery for pumping out their surplus sewage. Two open spaces for recreation have been provided by the Corporation at a cost of more than $f 2,000$; and contributions amounting to $\mathcal{f r}_{\mathrm{r} 04}$ a-year are made towards maintaining two open spaces which are not directly under the control of the Corporation. If we regard the improved paving

* In $1884,2,789$ water-closets were substituted for privies as a result of proceedings by the Sanitary Staff. 
of the streets as a measure likely to promote public health, then the money expended in that work $(£ 225,706)$, in new sewers $(£ 53,107)$, and in carrying out the improvements above referred to and some minor ones, amounts to $\&_{607}, 603$ is, $7 \mathrm{~d}$. This large sum has been obtained as "Sanitary Loans" since $r 880$.

There is still much to be done before the city can be regarded as incapable of further improvement by Corporation action. The private slaughterhouses should be abolished. Dairy-yards should be got rid of. Every remaining privy and built ash-pit should be wiped out. A main drainage system should be carried out. At least 7,000 more dwellings should be provided for the working classes.

Now let us see whether $\mathrm{cr}$ not the expenditure of $£ 607,000$, and ten years' sanitary labour, have resulted in any substantial improvement of the public health in Dublin. It is well known that sanitary reforms do not generally bear immediate fruit. It is, therefore, only towards the close of the decennial period of sanitary work in Dublin that we might expect to find a diminution in the enormous death-rate of Dublin.

The average death-rate in Dublin metropolitan area during the period $1876 \cdot 1880$ was $31^{1} 76$ per $\mathbf{r}, 000$ persons living. In the city the rate was $34^{\prime}$ I $\mathrm{r}$ per $\mathrm{T}, 000$, and in the suburbs 23.39 .

During the period $188 \mathrm{r}-188_{5}$, the death-rate in the whole area was 27.32 , in the city 30.34 , and in the suburbs 19.68. (I use, uncorrected, the Registrar-General's figures.)

In the period $x 886-1890$, the death-rate in the whole area was 26.3 , in the city 28.86 , and in the suburbs I9 86 .

In the period $1876 \cdot 1880$, the death-rate from the principal zymotic diseases in the whole registration area was 5.29 per $x, 000$ persons living; the rate in the city being 5.83 , and in the suburbs 3.27 . In the next quinquennial period, $188 \mathrm{r}-86$, the rate in the whole area was $3^{\circ} \cdot 06$, in the city $34^{2}$, and in the suburbs $2 \cdot 16$. During the period 1886 . $x 890$, the rate in the whole area was 2.86 , in the city $3^{\circ} 2$, and in the suburbs 2.02 .

Before the year 1879 , Io per cent. of the deaths were unregistered. In that year, owing to recent legislation, perfect registration first commenced, and the burrals no longer exceeded by ro per cent. the registered deaths, as was the case until early in 1879. I have, therefore, added Io per cent. to the recorded death-rate for $1876 \cdot 77-78$.

The causes of a high death-rate in communities may be nearly altogether capable of removal by the sanitary authority, or they may only to a moderate extent be of such a nature as to admit of removal by the sanitary authority. Poverty and intemperance are two potent factors in causing a high death-rate, and they are hardly under any control by the local authorities. The proportion of very poor persons in Dublin seem to me to be somewhat greater than in most of the English cities, certainly greater than in London. In all cities, it is undoubtedly the case that there is a greater mortality amongst the poor than amongst the middle and upper classes. It is not in the power of the Corporation of Dublin to provide employment and good wages for the masses of the population, and consequently constitutional and other diseases as affecting the poorer classes, are beyond Corporation influence. The effects of public hygiene are, however, felt in respect to zy motic diseases upon all classes. I think I shall show that the ten years'sanitary work in Dublin has apparently greatly reduced the zymotic death-rate, though it may not have very largely lowered the general death-rate.

The general death-rate declined in the period $\mathrm{I} 88 \mathrm{I}-85$, as compared with the previous quinquennial period, to the extent of 13.98 per cent. in the whole area, II 05 per cent. in the city, and 15.86 per cent. in the suburbs.

In the following five years the death-rate decreased 3.73 per cent. in the whole area, 4.88 per cent. in the city, and increased $0^{\circ} 9 \mathrm{I}$ per cent. in the suburbs.

The death-rate from the principal zymotic diseases decreased during the period $188 \mathrm{I}-85$, as compared with the previous five years, $42 \cdot 16$ per cent. in the whole area, $4^{*} 34$ per cent. in the city, and $33^{\circ} 39$ per cent. in the suburbs. In the follow ing five years the decrease was 6.44 per cent. in the whole area, 6.43 per cent. in the city, and 6.48 per cent. in the suburbs.

As compared with $\times 876.80$, the death.rate decreased in $188 \mathrm{x}-90 \times 5.59$ per cent. in the whole area, 13.22 per cent. in the city, and 15.48 per cent. in the suburbs; and the zymotic death-rate decreased 44.05 per cent. in the whole area, 43.23 per cent. in the city, and 36.09 per cent. in the suburbs.

The relation between the decrease in the mortality of the whole area, and that of the city and suburbs in $1880-85$, is affected by the circumstance, that in $188 \mathrm{r}$ four large and almost wholly rural districts were added to the Dublin Metropolitan Registration area. In the new districts the general and zymotic death-rates have been and are still lower than in the four suburbs which always formed part of the Dublin Metropolitan Registration area. The improvement of the public health in the city of Dublin has a good effect upon that of the suburbs, as a large proportion of the inhabitants of the suburbs are engaged in business in the city all day, and are subject to a large extent to whatever insanitary influences there may be in operation in the city.

In $189 \mathrm{r}$ the improvement in the state of public health of Dublin continues. During the first thirty weeks of the year the death-rate was 2.8 per 1,000 persons living, under the mean rate for the corresponding period in the previous ten years. 
The most remarkable feature in this year's (189r) mortality statistics is the close approximation of the zymotic death-rate in city and suburbs; indeed, in the first quarter of the year the zymotic death-rate was only $r$ per 1,000 in the city, whilst it was $r \cdot 2$ per $I, 000$ in the suburbs.

With respect to the particular zymotic diseases which have declined in Dublin within recent years, special reference must be made to typhus fever. This disease formerly caused terrible ravages in Dublin, but lately it has almost completely disappeared. On the other hand, typhoid fever has not decreased at all. Very few cases of diphtheria occur in Dublin. In 1890 the deatns in the city of Dublin per 10,000 persons attributed to typhoid fever were 49 , to typhus fever 07 , to diarrbœ 3 and dysentery 59, to whooping-cough 59 , to scarlet fever 2 , to measles 26 , to diphtheria $0^{\circ} 9$. Small-pox has long been extinct in Dublin.

A few years ago Dublin had a much higher death-rate than any of the large English towns; lately several English towns exceed it in mortality. With respect to its zymotic death-rate, Dublin now compares very favourably with the English towns.

In conclusion, I may again staite that the population of Dublin has been slightly under-estimated since $\mathrm{r} 88 \mathrm{I}$, bence its death-rate has been somewhat exaggerated. On the other hand, the population of the English towns has been (on the whole) enormously over-estimated, and consequently their death-rate under-stated. For example, if we correct the death-rates of Liverpool, Manchester, and Bolton for the period $188 \mathrm{I}-90$. by results of the census of 1891 , the rates will be: Liverpool, 26.3 per 1,000 ; Manchester, 26.6 ; and Bolton, 26.5 . In the period 1886.90 , the mean annual death-rate in Dublin was 26.3 .

The amount of money expended in Dublin since 1878 , for purposes more or less of a sanitary nature, amounts to a gross total of 6607,603 .

\section{BACTERIOLOGY.}

On a Bacillus found in a Case of Hamorrhagic Septicfemia Presenting Certain ChaRACTERS OF TyphUS. By T. BABES and T. OPRESCU.- "Annales de l'Institut Pasteur," No. 5 , May $25,189 \mathrm{r}$.

THE authers give a clinical description of a fatal case of fever, in which the patient had spots with a high temperature, and the general symptoms of typhus. From different organs, they separated a pathogenic bacillus and successfully cultivated it. Injected into mice and other small animals, it gave rise to bæmorrhages beneath the skin, high fever, and death; dogs were unaffected. It is suggested that the bacillus may be the cause of ordinary typhus.

\section{A NEW METHOD FOR THE DISPOSAL OF SEIVAGE, WITH SOME REFER- ENCES TO SCHEMES NOW IN USE.*}

By C. G. Moor, B.A. Cantab.

I.-In concluding a paper on methods of sewage treatment read at Burlington House at the recent Hygiene and Demography Congress, Dr. Thresh asked this question : "Do any of the processes mentioned, or any combination of such processes, enable us to get rid of our sewage in such a way as to give rise to no nuisance, cause no danger to health, and this at a cost sufficiently reasonable, considering the importance of attaining such results?"

In the opinion of most experts at the present day, the only answer that can be given to this inquiry is an emphatic negative.

We can see this from a brief consideration of those methods that are now in use; they may be divided into three classes:-

I. Lime processes.

2. Processes in which lime is not used.

3. Irrigation.

I. The first of these classes may be briefly disposed of ; the lime is used either alone or in com. bination with aluminous salts, or, as in Hanson's process, with the so-cailed sulphurous powder. In each of these cases a good effluent is the only thing aimed at, as the sludge is worthless.

It is also worthy of notice that where lime has been used to precipitate, it must also be added to press with. Under this head also comes the Amines process, in which herring brine is added to the lime with a view of sterilizing the sewage.

2. Processes in which lime is not used.-The best-known of these is the A B C, in which the sewage is precipitated by a mixture of clay, alum, and charcoal, with a little blood. A clear, inodorous, and tasteless effuent is produced, and the sludge is pressed without lime, dried, and ground; it is stated to contain 3 per cent. of ammonia, and 5 , per cent. of phosphates: both of these figures seem high if the manure sold has not been enriched by ammonia or phosphate. Much has been said for and against this process; at any rate it is better that the sludge, whatever it contains, should go on the land than have to be thrown away, as sometimes happens in the lime processes.

The International Sewage Purification Company precipitate with a mixture of magnetic oxide of iron and salts of iron, alumina, and magnesia. The effluent is further purified by passing through a filter bed of gravel and polarite. The sludge, when pressed without lime and dried, readily crumbles into a fine powder, and should be of some value as manure.

Webster's Process, or Electrical Treatment.-The

* Abstract of a Paper read before the British Association, Cardiff Meeting, 1891, Section B. 